\title{
Effects of hypoxia on growth and metabolism of juvenile turbot
}

\author{
K. Pichavant ${ }^{\mathrm{a} *}$, J. Person-Le-Ruyet ${ }^{\mathrm{a}}$, N. Le Bayon ${ }^{\mathrm{a}}$, A. Sévère $^{\mathrm{a}}, \mathrm{A}$. Le Roux ${ }^{\mathrm{a}}$, L Quéméner ${ }^{\mathrm{a}}$, \\ V.Maxime $^{b}$, G. Nonnotte ${ }^{b}$ and G Boeuf ${ }^{a}$ \\ a Laboratoire de Physiologie des Poissons, IFREMER, Centre de Brest, BP 70, 29280 Plouzané, France \\ ${ }^{b}$ Laboratoire de Physiologie des Systèmes Intégrés, Université de Bretagne Occidentale, 6 avenue le Gorgeu, \\ BP 809, 29285 Brest cédex, France \\ *: Tel.: +33-0298-2248-57; fax: +33-0298-2243-66; email: kpichava@ifremer.fr
}

\begin{abstract}
The effects of hypoxia on growth, feed efficiency, nitrogen excretion, oxygen consumption and metabolism of juvenile turbot $(120 \mathrm{~g})$ were studied in a 45-day experiment carried out in sea water at $17.0 \pm 0.5^{\circ} \mathrm{C}$ and $34.5 \mathrm{ppt}$ salinity. Fish were fed to satiation at O2-concentrations of $3.5 \pm 0.3,5.0 \pm 0.3$ mg I-1 (hypoxia) and $7.2 \pm 0.3 \mathrm{mg} \mathrm{I}-1$ (normoxia). Both feed intake (FI) and growth were significantly lower under hypoxia than under normoxia, with no significant differences being observed between 3.5 and $5.0 \mathrm{mg} \mathrm{O} 2 \mathrm{I}-1$. During the first 2 weeks of the experiment, $\mathrm{Fl}$ was halved under hypoxic conditions, and there were large differences among treatments in feed conversion ratio (FCR), i.e., it was 3.2, 1.5, and 0.9 in turbot exposed to $3.5,5.0$, and $7.2 \mathrm{mg} \mathrm{O} 2 \mathrm{I}-1$, respectively. Thereafter, FCR was not significantly affected by O2-concentration. Nitrogen excretion and oxygen consumption of feeding fish were significantly higher under normoxia than under hypoxia, but following 7 days of feed deprivation oxygen consumption was similar under normoxia and hypoxia. Plasma osmolarity, ionic balance, and acid-base status were not affected by the two hypoxic conditions tested. Overall, our results indicate that turbot have some capacity to adapt to relatively low ambient O2-concentrations.
\end{abstract}

Keywords: Turbot; Hypoxia; Growth; Feed utilization; Oxygen consumption; Nitrogen excretion; Ionregulation; Acid-base status 


\section{Introduction}

Low $\mathrm{O}_{2}$-concentrations are known to modify growth rate, feed efficiency and metabolism of fish (Brett, 1979; Jobling, 1994), but the long-term effects of reduced environmental $\mathrm{O}_{2}$-concentrations have been elucidated for only a few fish species (Brett \& Blackburn, 1981; Cech et al., 1984; Pedersen, 1987; Van Dam \& Pauly, 1995).

Some data relating to the environmental requirements of juvenile turbot (Scophthalmus maximus) are available. The species is relatively euryhaline, and growth and osmolarity disturbances are only observed below 6 ppt (Waller, 1992; Gaumet et al., 1995). The optimal temperature for growth of juveniles is $16-20{ }^{\circ} \mathrm{C}$ (Burel et al., 1996), and this is not markedly affected by photoperiod in the period prior to sexual maturity (Imsland et al., 1995, 1997; Pichavant et al., 1998). Turbot are relatively tolerant to ammonia: no growth reduction is observed below $0.1 \mathrm{mg} \mathrm{l}^{-1}$ UIA-N (unionised form of ammonia), but above 0.8 $\mathrm{mg} \mathrm{l}^{-1}$ UIA-N growth ceases (Person-Le-Ruyet et al., 1997). Little is known about the effects of hypoxia, with data mainly relating to acute survival (Person-Le-Ruyet, 1993) or rates of oxygen consumption measured under different environmental conditions (Brown et al., 1984; Waller, 1992; Gaumet et al., 1995; Burel et al., 1996).

The present study was undertaken to examine the long-term effects of $\mathrm{O}_{2}$ concentrations on feeding, growth, feed utilization and nitrogen excretion in juvenile turbot. The study was carried out over 45 days in an attempt to highlight the strategies used by the fish to adapt to hypoxia: oxygen consumption was measured at different $\mathrm{O}_{2}$-concentrations, and blood was sampled for monitoring of the physiological status of the fish.

\section{Materials and methods}

\subsection{Fish and rearing conditions}

The experiment was carried out on 480 six-month old hatchery-reared juvenile turbot. Fish had been reared at IFREMER, Brest $\left(48^{\circ} \mathrm{N}\right)$ according to methods described by PersonLe-Ruyet et al. (1991).

The experiment was performed in $1 \mathrm{~m}^{2}$ Swedish-type tanks, with an effective water volume of $450 \mathrm{l}$. Tanks were supplied with a continuous flow of water at $17.0 \pm 0.5^{\circ} \mathrm{C}$ and 34-34.5 ppt salinity. The photoperiod was maintained at $16 \mathrm{~L}: 8 \mathrm{D}$, and light intensity at the water surface was $2 \mathrm{~W} \cdot \mathrm{m}^{-2}$. Ambient $\mathrm{pH}$ and ammonia concentration were monitored at 4-day intervals.

The fish, divided into groups of 80, were randomly distributed amongst 6 tanks and were then allowed to adapt to the rearing and feeding conditions for 4 weeks under normoxia $\left(\mathrm{O}_{2}\right.$-concentration $\left.=7.2 \mathrm{mg} \mathrm{l}^{-1}\right)$. They were fed by hand to apparent satiation (feed intake was assumed to equal to feed provision) twice a day with a commercial dry pellet (Le Gouessant, $4.5 \mathrm{~mm}$ diameter; total protein and crude fat $59.1 \%$ and $19.8 \%$ of dry matter respectively). 


\subsection{Experimental design}

After the adaptation period, the fish were exposed to one of the following $\mathrm{O}_{2}$ concentrations for 45 days, i.e. either $7.2 \mathrm{mg} \mathrm{l}^{-1}$ (95\% of $\mathrm{O}_{2}$-saturation, control tanks, normoxia), or $5.0 \mathrm{mg} \mathrm{l}^{-1}$ (65\% of $\mathrm{O}_{2}$-saturation), or $3.5 \mathrm{mg} \mathrm{l}^{-1}$ (45\% of $\mathrm{O}_{2}$-saturation). The experiment was conducted on replicated groups of fish (initial weight: $120 \pm 5 \mathrm{~g}$, mean $\pm \mathrm{se}$ ) for each $\mathrm{O}_{2}$-concentration. Water flow rates were 10 and $15 \mathrm{lmin}^{-1}$ under hypoxic and normoxic conditions, respectively.

At day 0 , start of the experiment, $\mathrm{O}_{2}$-concentrations in the inflowing water were decreased, and the desired levels were achieved within 4 hours. These levels were then maintained until the end of the experiment. Decreases in $\mathrm{O}_{2}$-concentration were obtained using an oxygen depletion system (Fig. 1) adapted from Bennett \& Beitinger (1995). Sea water first flowed through an open aeration column packed with polypropylene spheres, and then through a column where nitrogen was injected. Oxygen removal was controlled by the nitrogen flow, and total gas pressure was measured with a tensionometer (300C Novatech ${ }^{\circledR}$ ). Surface gas exchange in the rearing tanks was limited by setting the water inflow under the water surface. The $\mathrm{O}_{2}$-concentration in each tank was checked manually twice a day, and adjusted when necessary. It was also monitored semi-continuously (two 24 h-cycles per week minimum) as described by Gaumet et al. (1995).

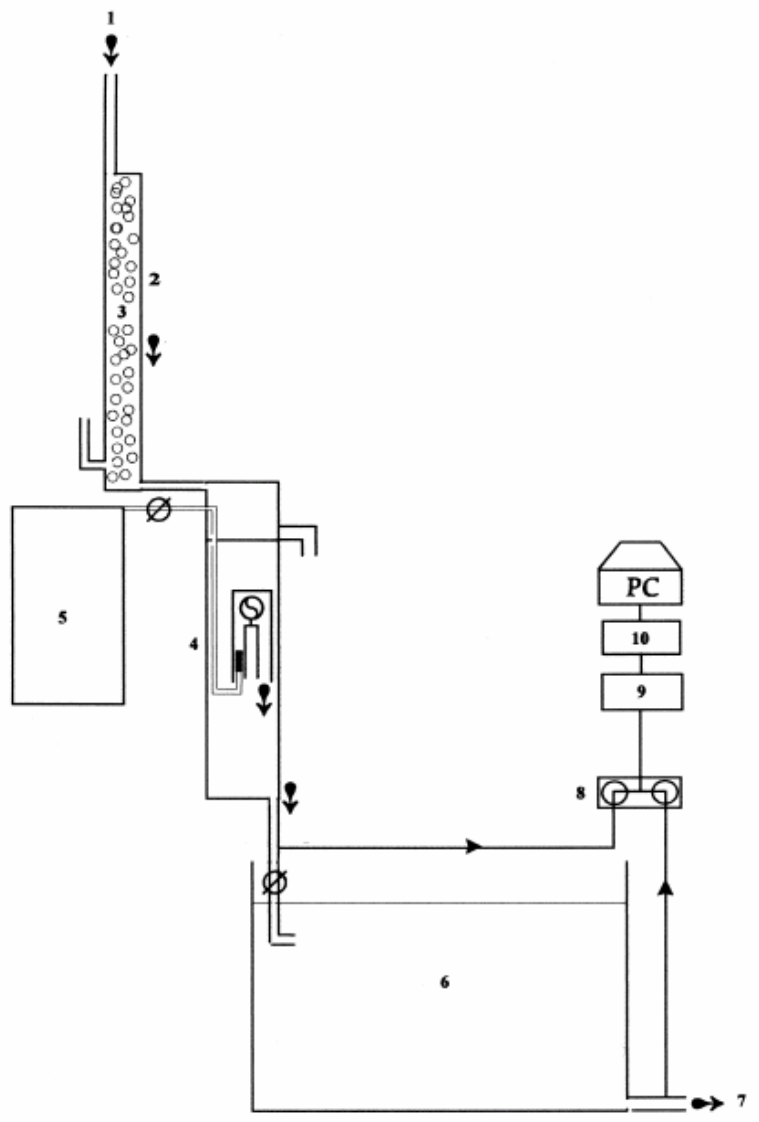

Fig 1. Experimental set-up showing rearing tanks, oxygen depletion system and environmental monitoring. 1: water inflow, 2: aeration column, 3: polypropylene spheres, 4: nitrogen injection system, 5: nitrogen tank, 6: rearing tank, 7: water outflow, 8: solenoid valves, 9: $\mathrm{O}_{2}$ measuring cell, 10: oxymeter, PC : computer, $\rightarrow$ : direction of sea water flow, $(\mathcal{Q}$ : pump, $\varnothing$ : solenoid valves, $>$ : inlet and outlet sea water sample. 


\subsection{Studied parameters}

All fish in each tank were individually weighed to the nearest $0.1 \mathrm{~g}$ at 15 days intervals. Prior to weighing fish had been fasted for $18 \mathrm{~h}$, without anesthesia. Feed utilization parameters were calculated as follows:

-apparent feed conversion ratio (FCR): feed provided per unit biomass gain ;

-daily feed intake (FI): $100 \times$ (feed provided per day per unit biomass);

-protein efficiency ratio (PER): biomass gain per unit feed protein provided;

-protein utilization coefficient (PUC): $100 \times$ (protein gain per unit feed protein provided).

Fish body composition was determined using freeze-dried samples of $3 \times 10$ fish from the initial population and $3 \times 8$ fish per tank (6 samples per $\mathrm{O}_{2}$-concentrations tested) at the end of the experiment. Chemical analyses of food and fish were performed in triplicate for each sample according to AOAC (1984) methods, i.e. dry matter (24h at $\left.105^{\circ} \mathrm{C}\right)$, ash (7h at $550^{\circ} \mathrm{C}$ ), crude lipid (dichloromethane extraction with an automatic Soxtec system $\mathrm{Ht}^{\circledR}$, Perstorp Analytical) and crude protein determined from nitrogen concentration $(\mathrm{N} \times 6.25)$ by Dumas method with an Elementary NA $2000^{\circledR}$, Thermo Separation Products.

Total ammonia nitrogen (TAN) and urea-N concentrations of the inlet and outlet water were measured according to the procedures described in Dosdat et al. (1994). Measurements were undertaken over three consecutive days (32-35), using sequential sampling for 24 hours by a peristaltic pump. These data were used to estimate average daily excretion rates, expressed in mg TAN or urea-N kg bw (body weight) ${ }^{-1}$ day $^{-1}$, and body weight was estimated by extrapolation of growth curve between days 30 and 45 . Concomittantly, the daily excretion patterns were examined by manual water sampling each hour, and hourly excretion rates were expressed in mg TAN or urea- $\mathrm{N} \mathrm{kg} \mathrm{bw}{ }^{-1} \mathrm{~h}^{-1}$.

Oxygen consumption $\left(\mathrm{MO}_{2}\right)$ was determined for both fed fish and fish deprived of food for 7 days (monitored in darkness) according to the method described in Gaumet et al. (1995). $\mathrm{MO}_{2}$ was monitored each 15 min using the difference in $\mathrm{O}_{2}$-concentration between the water inflow $\left(\mathrm{O}_{2}\right.$ inlet) and outflow $\left(\mathrm{O}_{2}\right.$ outlet) of each tank. After correction for $\mathrm{O}_{2}$ variations measured in a similar tank without fish, $\mathrm{MO}_{2}$ was calculated as follows: $\mathrm{MO}_{2}=\left(\mathrm{O}_{2}\right.$ inlet - $\mathrm{O}_{2}$ outlet) Qw bw ${ }^{-1}$ where Qw is the water flow through the tank, and bw is the fish body weight. $\mathrm{MO}_{2}$ was expressed in $\mu \mathrm{mol} \mathrm{O} \mathrm{g} \mathrm{bw}^{-1} \mathrm{~h}^{-1}$.

At intervals (day 0, 2, 7, 15, 30,45), blood samples were obtained by puncture of caudal vessels from fish fasted for 18 hours ( 3 fish per tank on day 0 and 6 fish per tank from day 2 to day 45). Haematocrit and blood $\mathrm{pH}$ (Metrohm ${ }^{\circledR}$ pHmeter fitted with a microflow $\mathrm{pH}$ sensor) were determined immediately after blood sampling. Blood plasma total $\mathrm{CO}_{2}$ concentrations were measured using a Sigma Diagnostics enzymatic kit (132-UV) within 15 minutes. All other blood analyses were performed on plasma samples that had been stored frozen: osmolarity, chloride, sodium and potassium concentrations as described by Gaumet $e t$ al. (1995) and TAN, urea-N, and lactate concentrations using Sigma Diagnostics enzymatic kits (171-UV, Urea Nitrogen-535, and 735-UV). Plasma cortisol concentrations were measured by a specific radioimmunoassay adapted from Lamers et al. (1992). 


\subsection{Data analysis}

Statistical analyses were conducted using STATISTICA for Windows. All results are expressed as mean \pm se. Differences in weight, blood parameters concentrations, daily nitrogen excretion and $\mathrm{O}_{2}$-consumption were tested by a nested-ANOVA, and tanks were considered as nested factor. One-way ANOVA was used for feed intake, feed conversion ration, protein efficiency ratio and protein utilization coefficient. Significant ANOVA were followed by a post hoc multiple comparison test (Newman-Keuls test). Differences were considered significant at $\mathrm{P}<0.05$. Prior to analysis (ANOVA and post hoc multiple comparison test), data expressed in \%, were arcsinus scare-root transformed.

\section{Results}

\subsection{Effects of hypoxia on growth performance, feed intake and feed efficiency}

$\mathrm{O}_{2}$-concentrations were maintained close to predetermined levels throughout the 45day experiment. Fish appeared healthy throughout all treatments, and there was no mortality in any group.

Exposure to hypoxia markedly depressed the growth of the turbot (Fig. 2A). From day 0 to day 15 , the fish exposed to $3.5 \mathrm{mg} \mathrm{O}_{2} \mathrm{l}^{-1}$ gained very little weight, and at $5.0 \mathrm{mg} \mathrm{O}_{2} \mathrm{l}^{-1}$ weight gain was much reduced than in the normoxic control. Thereafter, hypoxic groups displayed some improvement in growth, but the final mean weight was $25 \%$ lower under the two hypoxic conditions than under normoxia (without any significant differences between the two hypoxic conditions after day 30).

There were also differences among groups in feed intake (FI) and efficiency (Fig. 2B, 2C). FI was positively correlated with ambient $\mathrm{O}_{2}$-concentration. During the first two weeks of the experiment, FI in fish exposed to 3.5 and $5.0 \mathrm{mg} \mathrm{l}^{-1}$ was only half that of fish under normoxia, and apparent feed conversion ratios (FCR) were high. Thereafter, differences in FI between the three groups were somewhat reduced, and FCR was similar amongst all groups. No significant differences were observed in final body composition of fish except for relative protein content under $3.5 \mathrm{mg} \mathrm{O}_{2} \mathrm{l}^{-1}$ (Table 1). Protein efficiency ratios (PER) were similar (23-24\%) at 5.0 and $3.5 \mathrm{mg} \mathrm{O}_{2} \mathrm{l}^{-1}$, and significantly higher at $7.2 \mathrm{mg} \mathrm{O}_{2} \mathrm{l}^{-1}$ (27\%). In the same way, protein utilization coefficient (PUC) was related to $\mathrm{O}_{2}$-concentration: it was 1.21.3 at 5.0 and $3.5 \mathrm{mg} \mathrm{O}_{2} \mathrm{l}^{-1}$ and 1.9 at $7.2 \mathrm{mg} \mathrm{O}_{2} \mathrm{l}^{-1}$. 

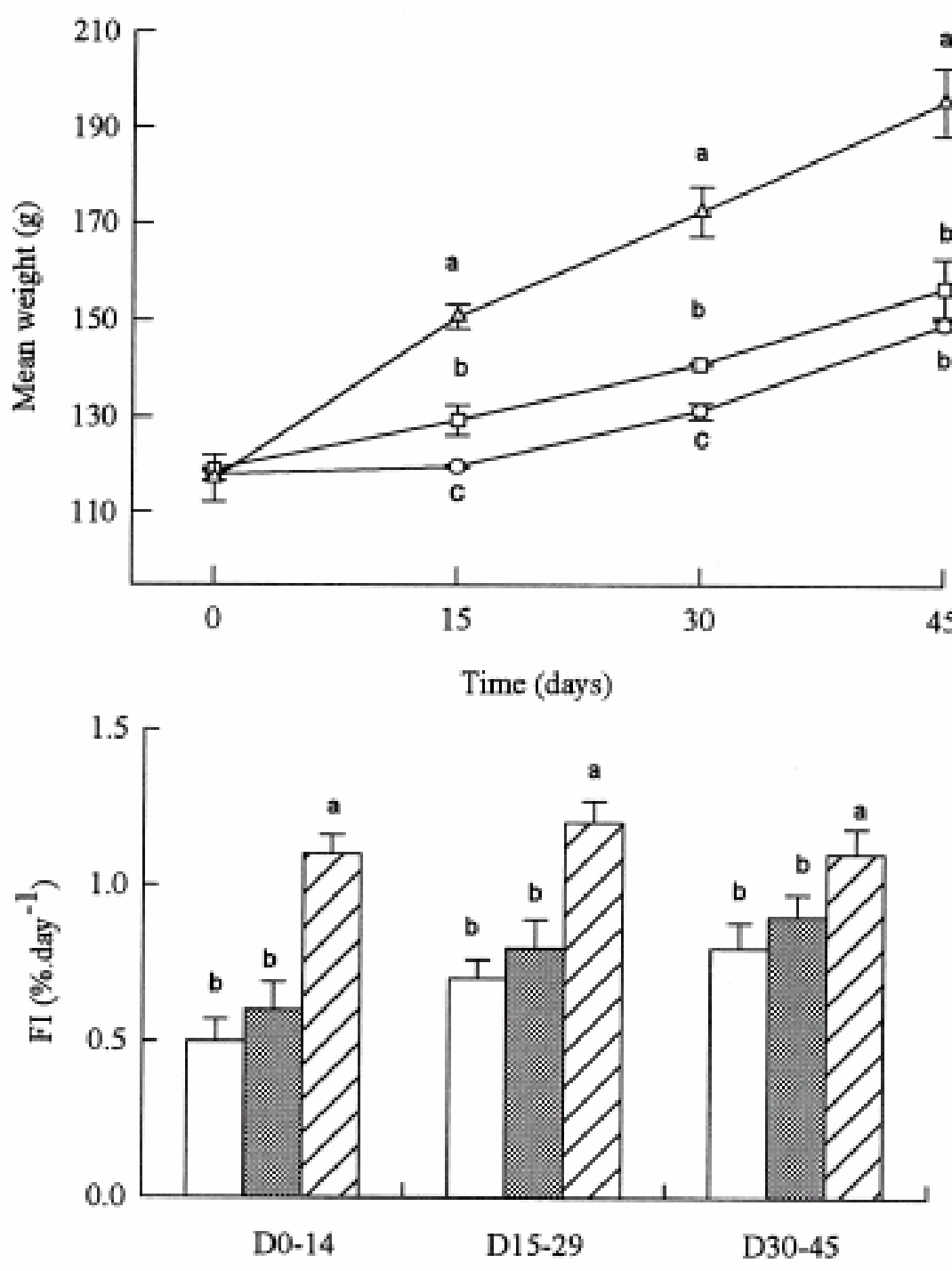

B

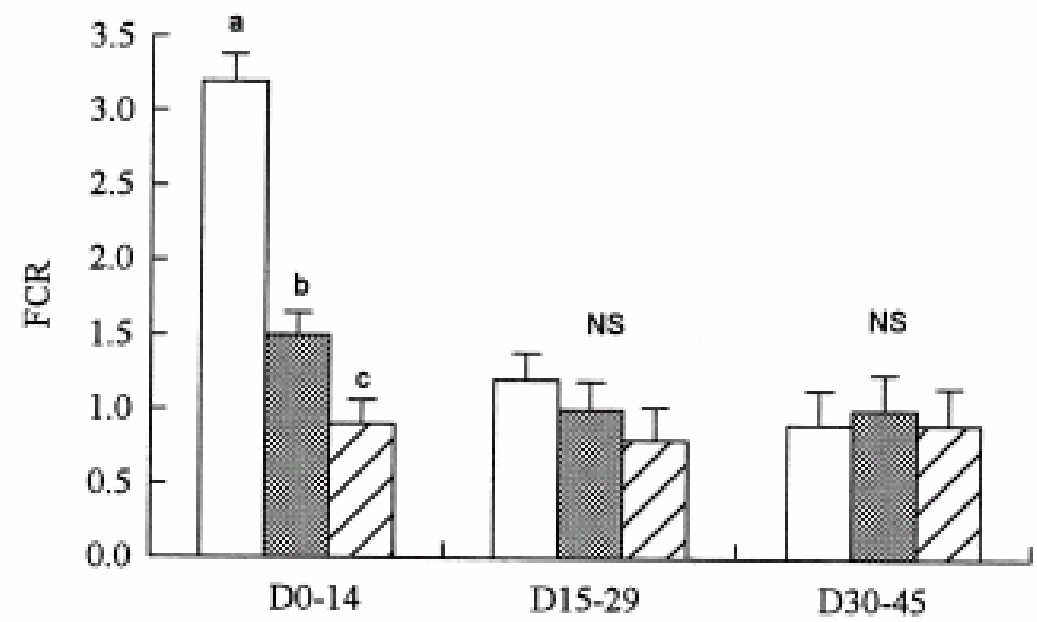

Fig. 2. Change of mean weight over time in turbot (2A) in relation to $\mathrm{O}_{2}$-concentration: 3.5 (o), 5.0 ( $\square$ ) and 7.2 $(\Delta) \mathrm{mg} \mathrm{O}_{2} \mathrm{l}^{-1}$. Means are given with standard errors ( $\mathrm{n}=2$ replicates). Change of feed provisionning over time (FI, 2B) and feed conversion ratio (FCR, 2C) in relation to $\mathrm{O}_{2}$-concentration : $3.5 \square$ ), $5.0(\square)$ and $7.2(\square \Delta$ ) Letters indicate intergroup statistical differences with means not sharing a common letter being significantly different $(\mathrm{P}<0.05)$. NS = no significant difference $(\mathrm{P}>0.05)$. 
Table 1. Day O and day 45 body composition (\% of body weight) of turbot in relation to O2-concentration. Means are given with standard errors $(n=2$ replicates). Letters indicate intergroup statistical differences with means not sharing a common letter being significantly different $(\mathrm{P}<0.05)$. NS $=$ no significant difference $(\mathrm{P}>$ 0.05).

\begin{tabular}{cccccc}
\hline & {$\left[\mathrm{O}_{2}\right]\left(\mathrm{mg} \mathrm{l}^{-1}\right)$} & Water (\%) & Protein (\%) & Fat (\%) & Ash (\%) \\
\hline Day 0 & $7.2 \pm 0.3$ & $78.2 \pm 0.3$ & $15.1 \pm 0.5$ & $2.0 \pm 0.2$ & $4.0 \pm 0.3$ \\
\hline \multirow{2}{*}{ Day 45 } & $3.5 \pm 0.3$ & $77.5 \pm 1.5$ & $16.3 \pm 0.9^{\mathrm{a}}$ & $2.2 \pm 0.1$ & $4.1 \pm 0.3$ \\
& $5.0 \pm 0.3$ & $78.2 \pm 1.5$ & $15.1 \pm 0.6^{\mathrm{b}}$ & $2.4 \pm 0.7$ & $3.8 \pm 0.1$ \\
& $7.2 \pm 0.3$ & $77.7 \pm 0.3$ & $14.9 \pm 0.4^{\mathrm{b}}$ & $2.6 \pm 0.2$ & $3.5 \pm 0.2$ \\
& & NS & & NS & NS \\
\hline
\end{tabular}

\subsection{Oxygen consumption}

Oxygen consumption $\left(\mathrm{MO}_{2}\right)$ in fed fish started to increase 2 hours after each meal, and reached a maximum 4 to 5 hours later (Fig. 3A). In these fish, $\mathrm{MO}_{2}$ was lower under hypoxia than under normoxia, as seen by examination of the average oxygen consumption rate of fed turbot (Fig. 3B). Following a 7-day period of feed deprivation in darkness, the $\mathrm{MO}_{2}$ was two to threefold lower than that of fed fish, and no significant differences were noticed between groups (Fig. 3B). 

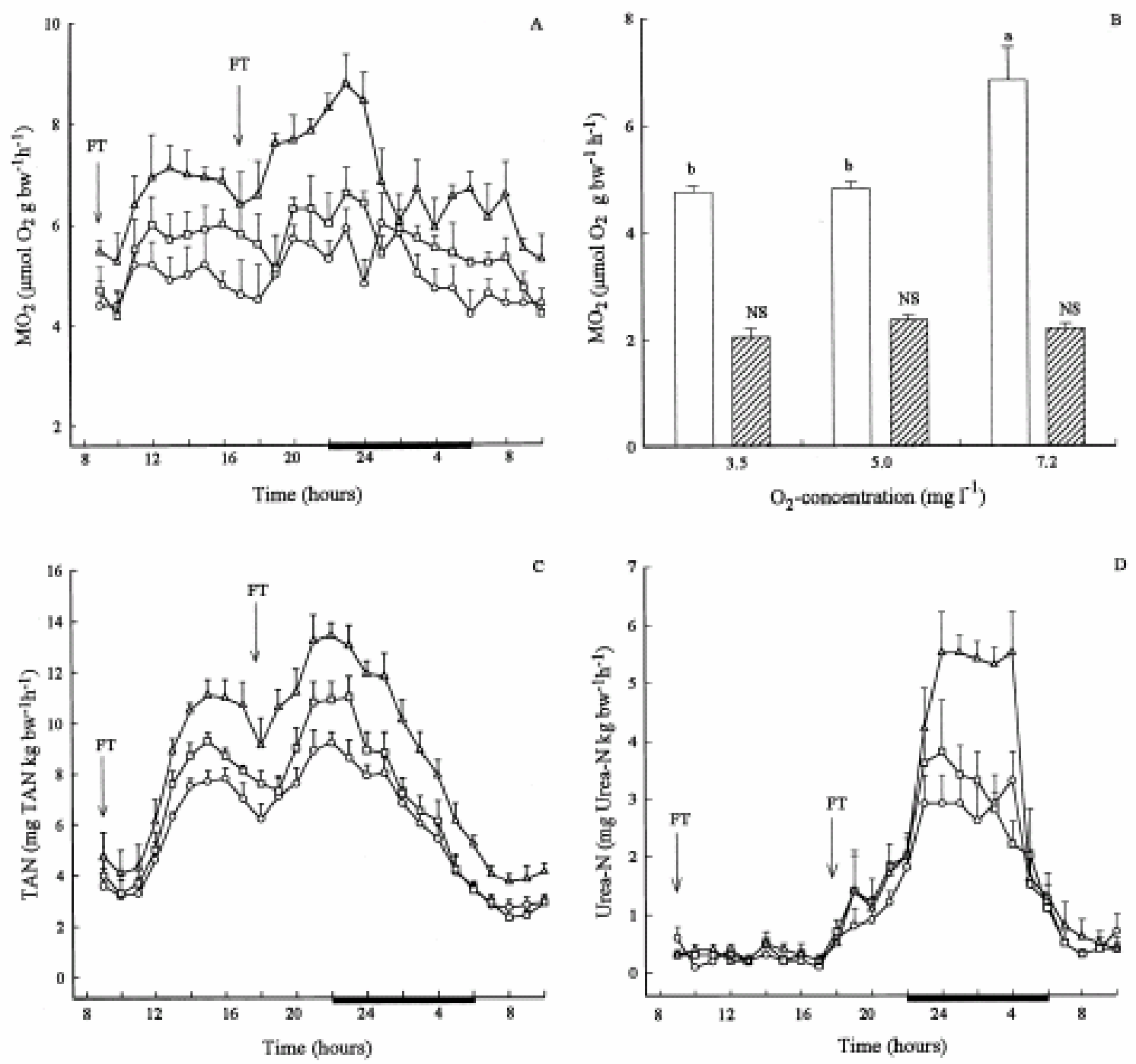

Fig. 3. Daily patterns of oxygen consumption $\left(\mathrm{MO}_{2}\right)$ of turbot (3A) held at different $\mathrm{O}_{2}$-concentrations: 3.5 (o), $5.0(\square)$ and $7.2(\Delta) \mathrm{mg} \mathrm{O}_{2} \mathrm{l}^{-1}$. Data are means with standard errors ( $\mathrm{n}=2$ replicates).

Average $\mathrm{MO}_{2}$ of fed ( $\square$ ) turbot and of resting ( turbot (deprived of food for 7 days and in darkness) in relation to $\mathrm{O}_{2}$-concentration (3B). Means are given with standard errors ( $\mathrm{n}=2$ replicates). Letters indicate intergroup statistical differences with means not sharing a common letter being significantly different $(\mathrm{P}<0.05)$. NS = no significant difference $(\mathrm{P}>0.05)$.

Daily patterns of total ammonia nitrogen, TAN (3C) and urea-N excretion (3D) in turbot in relation to $\mathrm{O}_{2}$ concentration : $3.5(\mathrm{o}), 5.0(\square)$ and $7.2(\Delta) \mathrm{mg} \mathrm{O}_{2} \mathrm{l}^{-1}$. Data are means with standard errors ( $\mathrm{n}=2$ replicates). The horizontal bar on $\mathrm{x}$-axis indicates the dark phase of photoperiod, and $\rightarrow$ is feeding time.

\subsection{Nitrogen excretion}

The average daily TAN excretion rate was significantly affected by $\mathrm{O}_{2}$ concentration, i.e. $151.3 \pm 6.5,170.6 \pm 4.6$ and $219.6 \pm 9.1 \mathrm{mg} \mathrm{TAN} \mathrm{kg} \mathrm{bw}^{-1} \mathrm{day}^{-1}$ at 3.5, 5.0 and $7.2 \mathrm{mg} \mathrm{O}_{2} \mathrm{l}^{-1}$, respectively. The average daily urea-N excretion rate was also dependent on $\mathrm{O}_{2}$-concentration and was equal to $29.4 \pm 4.1$, $33.6 \pm 5.2$ and $43.2 \pm 2.8 \mathrm{mg}$ Urea-N kg bw ${ }^{-}$ ${ }^{1}$ day $^{-1}$ at 3.5, 5.0 and $7.2 \mathrm{mg} \mathrm{O}_{2} \mathrm{l}^{-1}$, respectively. Some differences in the magnitude of daily patterns of TAN and urea-N excretion were observed between groups although general trends 
tended to be similar. TAN excretion increased 3 hours after each meal (Fig. 3C), and a delayed single urea-N excretion peak occurred during the dark phase (Fig. 3D).

\subsection{Fish physiological status}

No significant differences among any of the physiological indicators tested were noticed (Tables 2, 3).

Table 2. Blood parameters at day 0 and 45 of turbot in relation to $\mathrm{O}_{2}$-concentration. Means are given with standard errors ( $\mathrm{n}=2$ replicates). NS $=$ no significant difference $(\mathrm{P}>0.05)$.

\begin{tabular}{|c|c|c|c|c|c|}
\hline & Day 0 & Day 45 & Day 45 & Day 45 & \\
\hline$\left[\mathrm{O}_{2}\right]\left(\mathrm{mg} \mathrm{l}^{-1}\right)$ & $7.2 \pm 0.3$ & $3.5 \pm 0.3$ & $5.0 \pm 0.3$ & $7.2 \pm 0.3$ & \\
\hline osmolarity (mosm $\mathrm{l}^{-1}$ ) & $308 \pm 3$ & $310 \pm 2$ & $309 \pm 3$ & $310 \pm 2$ & NS \\
\hline $\mathrm{Cl}^{-}\left(\mathrm{mmol} \mathrm{l} \mathrm{l}^{-1}\right)$ & $144 \pm 2$ & $146 \pm 2$ & $146 \pm 2$ & $145 \pm 1$ & NS \\
\hline $\mathrm{Na}^{+}\left(\mathrm{mmol} \mathrm{l} \mathrm{l}^{-1}\right)$ & $155.3 \pm 2.4$ & $154.1 \pm 1.8$ & $156.6 \pm 2.1$ & $156.5 \pm 2.0$ & NS \\
\hline $\mathrm{K}^{+}\left(\mathrm{mmol} \mathrm{l} \mathrm{l}^{-1}\right)$ & $3.6 \pm 0.2$ & $3.5 \pm 0.1$ & $3.4 \pm 0.2$ & $3.4 \pm 0.1$ & NS \\
\hline TAN (mg l $\left.{ }^{-1}\right)$ & $3.0 \pm 0.3$ & $2.7 \pm 0.4$ & $2.9 \pm 0.3$ & $3.2 \pm 0.2$ & NS \\
\hline urea-N (mg dl ${ }^{-1}$ ) & $13.7 \pm 0.8$ & $12.4 \pm 0.5$ & $13.1 \pm 0.4$ & $14.1 \pm 0.6$ & NS \\
\hline haematocrit (\%) & $20 \pm 2$ & $19 \pm 2$ & $18 \pm 3$ & $21 \pm 3$ & NS \\
\hline Cortisol (ng ml ${ }^{-1}$ ) & $2.9 \pm 0.5$ & $3.0 \pm 0.8$ & $3.0 \pm 0.7$ & $3.1 \pm 0.7$ & NS \\
\hline
\end{tabular}

Table 3. Change of blood acid-base status over time of turbot in relation to $\mathrm{O}_{2}$-concentration. Means are given with standard errors $(\mathrm{n}=2$ replicates $)$. NS = no significant difference $(\mathrm{P}>0.05)$.

\begin{tabular}{|c|c|c|c|c|c|c|c|c|}
\hline$\left[\mathrm{O}_{2}\right]\left(\mathrm{mg} \mathrm{l}^{-1}\right)$ & & Day 0 & Day 2 & Day 7 & Day 15 & Day 30 & Day 45 & \\
\hline $3.5 \pm 0.3$ & & & $7.74 \pm 0.31$ & $7.63 \pm 0.21$ & $7.80 \pm 0.24$ & $7.77 \pm 0.23$ & $7.82 \pm 0.28$ & NS \\
\hline $5.0 \pm 0.3$ & $\mathrm{pH}$ & $7.68 \pm 0.22$ & $7.65 \pm 0.17$ & $7.72 \pm 0.28$ & $7.75 \pm 0.19$ & $7.61 \pm 0.26$ & $7.79 \pm 0.24$ & NS \\
\hline $7.2 \pm 0.3$ & & & $7.75 \pm 0.26$ & $7.63 \pm 0.16$ & $7.72 \pm 0.14$ & $7.72 \pm 0.19$ & $7.80 \pm 0.21$ & NS \\
\hline $3.5 \pm 0.3$ & & & $7.7 \pm 0.4$ & $7.8 \pm 0.4$ & $8.1 \pm 0.3$ & $8.2 \pm 0.2$ & $8.0 \pm 0.1$ & NS \\
\hline $5.0 \pm 0.3$ & $\begin{array}{l}\text { Total } \mathrm{CO}_{2} \\
\left(\mathrm{mmol} \mathrm{l}^{-1}\right)\end{array}$ & $8.4 \pm 0.2$ & $8.5 \pm 0.3$ & $8.1 \pm 0.1$ & $8.2 \pm 0.2$ & $8.5 \pm 0.3$ & $8.1 \pm 0.5$ & NS \\
\hline $7.2 \pm 0.3$ & & & $8.5 \pm 0.3$ & $8.4 \pm 0.4$ & $8.2 \pm 0.3$ & $8.1 \pm 0.2$ & $8.6 \pm 0.3$ & NS \\
\hline $3.5 \pm 0.3$ & & & $0.04 \pm 0.02$ & $0.02 \pm 0.01$ & $0.04 \pm 0.02$ & $0.04 \pm 0.02$ & $0.07 \pm 0.04$ & NS \\
\hline $5.0 \pm 0.3$ & $\begin{array}{c}\text { Lactate } \\
\left(\mathrm{mmol} \mathrm{l}^{-1}\right)\end{array}$ & $0.04 \pm 0.02$ & $0.03 \pm 0.02$ & $0.02 \pm 0.01$ & $0.02 \pm 0.01$ & $0.02 \pm 0.01$ & $0.03 \pm 0.02$ & NS \\
\hline $7.2 \pm 0.3$ & & & $0.03 \pm 0.01$ & $0.04 \pm 0.01$ & $0.02 \pm 0.01$ & $0.02 \pm 0.01$ & $0.03 \pm 0.02$ & NS \\
\hline
\end{tabular}




\section{Discussion}

During the 45-day experiment, in juveniles turbot, there was a marked reduction of feed intake, decrease in growth and a temporary reduction of feed conversion efficiency with a decrease in environmental $\mathrm{O}_{2}$-concentrations. Similar responses had been previously observed in some other fish species (Brett, 1979; Brett \& Blackburn, 1981; Pedersen, 1987; Pouliot \& De La Noüe, 1989; Van Dam \& Pauly, 1995). Fish exposed to reduced $\mathrm{O}_{2}$ concentrations respond both with energy saving strategies and with responses to maintain the supply of oxygen to the tissues. In hypoxia, the reduction of feed intake may be interpretated as a way to reduce energy demand and thereby decrease $\mathrm{O}_{2}$ requirements (Van Dam \& Pauly, 1995). Below an $\mathrm{O}_{2}$-concentration threshold, feed intake may be suppressed due to the fact that reduced oxygen availability would be unable to sustain the high energy demands of a well-fed fish. A preliminary test showed us that turbot ceased feeding below 2-2.5 $\mathrm{mg} \mathrm{O}_{2} \mathrm{l}^{-1}$. The reduction of feed intake at 3.5 and $5.0 \mathrm{mg} \mathrm{O}_{2} \mathrm{l}^{-1}$ had consequences for growth (25\% decrease in 45 days in this study). Comparisons with other studies are difficult due to differences in hypoxia duration, fish size, nature of diet or temperature applied. Nevertheless, it is generally agreed that oxygen acts as a limiting factor for growth, and in some species (salmonids, Oncorhynchus kisutch, socheye, O. nerka, largemouth bass, Micropterus salmoides, carp, Cyprinus carpio and european sea bass, Dicentrarchus labrax) growth has been reported to become dependent on $\mathrm{O}_{2}$-concentration below 4 to $5 \mathrm{mg} \mathrm{l}^{-1}$ (Brett, 1979; Brett \& Blackburn, 1981 ; Thetmeyer et al., 1999) whereas in rainbow trout, O. mykiss, the threshold $\mathrm{O}_{2}$-concentration for growth seems higher, $7 \mathrm{mg} \mathrm{l}^{-1}$ (Pedersen, 1987).

In the study reported here, the daily $\mathrm{O}_{2}$-consumption of the fed turbot was strongly dependent on $\mathrm{O}_{2}$-concentration. It is possible that, to save energy, turbot submitted to hypoxia were less active than those under normoxia, and this may have contributed to the decreased rate of $\mathrm{O}_{2}$-consumption. However, Jobling \& Davies (1980) showed that the increase in rate of $\mathrm{O}_{2}$-consumption after feeding was strongly correlated with meal size and duration, the post-prandial increase in $\mathrm{MO}_{2}$ of fed fish resulting from the energy requirements for digestion and absorption, biosynthesis and storage of nutrients (Jobling, 1994). Thus, the feed intake reduction amongst turbot exposed to hypoxia may explain much of the decrease in postprandial $\mathrm{O}_{2}$-consumption rate observed in our experiment: the feed intake of fish exposed to hypoxia was twice less than the one of fish submitted to normoxia.

Within the range of $\mathrm{O}_{2}$-concentrations tested, hypoxia did not affect $\mathrm{MO}_{2}$ of unfed turbot. Most teleosts are oxygen regulators, and are able to regulate rates of $\mathrm{O}_{2}$-consumption independently of environmental oxygen over a wide range (Fristche \& Nilsson, 1993). Indeed, $\mathrm{O}_{2}$-consumption rates cannot be maintained independent of environmental $\mathrm{O}_{2}$-levels indefinitely, and at some critical $\mathrm{O}_{2}$-concentration oxygen uptake will be limited by, and become dependent upon down to the ambient level. In unfed turbot, $\mathrm{MO}_{2}$ can be maintained down to $1 \mathrm{mg} \mathrm{O}_{2} \mathrm{l}^{-1}$, the concentration that is close to the lethal $\mathrm{O}_{2}$-concentration for this species (Person-Le-Ruyet, 1993; Maxime et al., in press).

TAN excretion was also dependent on $\mathrm{O}_{2}$-concentration, and closely follows the feed intake pattern under hypoxia; TAN excretion is strongly correlated with meal size and duration (Kaushik, 1980; Dosdat et al., 1995). In turbot, urea excretion occured during a single pulse of 4-5 hours duration, this pulsatile excretion being related to the change from light to darkness (Pichavant et al., 1998). 
The physiological responses of fish to hypoxia are dependent on species, intensity and exposure duration (Jensen et al., 1993). The results reported here showed that, in turbot, an exposure to moderate hypoxia (45\% of $\mathrm{O}_{2}$-saturation) had no long-term effect on hydromineral balance or acid-base status; moreover no sign of stress was noticed. These data were in agreement with those reported on another flatfish, the sole, Solea solea in which no major change in the physiological status was observed after a 12-hour exposure to a hypoxic challenge of $40 \% \mathrm{O}_{2}$-saturation (Dalla Via et al., 1994; Thillart et al., 1994). This suggests that flatfish can adapt rapidly and effectively to $\mathrm{O}_{2}$-concentrations as low as 3.2-3.5 $\mathrm{mg} \mathrm{l}^{-1}$. This adaptation is attributable to several changes that may occur during long-term exposure to non-lethal hypoxia: increases in the oxygen-transporting capacity (increase of $\mathrm{O}_{2}$ haemoglobin affinity, blood volume or haemoglobin concentration) or increase in the tissue glycogen reserves (Jobling, 1994). Further investigations are required to elucidate the mechanisms involved in this adaptation in turbot.

\section{Acknowlegments}

The authors thank H. Le Delliou and B. Petton for technical assistance. This study was supported by an extra-Ifremer grant : PR 'Régulation de la croissance chez les poissons'.

\section{References}

Association of Official Analytical Chemists (AOAC), 1984. Official methods of analysis of the Association of Official Analytical Chemists. In: Williams, S. (Ed.), AOAC. Arlington, VA, $1141 \mathrm{pp}$.

Bennett, W., Beitinger, T.L., 1995. Overview of techniques for removing oxygen from water and a description of a new oxygen depletion system. Prog. Fish Cult. 57, 84-87.

Brett, J.R., 1979. Environmental factors and growth. In: Hoar, W.S., Randall, D.J., Brett, J.R. (Eds.), Fish Physiology, Vol. VIII. Academic Press, New York, pp. 599-675.

Brett, J.R., Blackburn, J.M., 1981. Oxygen requirements for growth of young coho (Oncorhynchus kisutch) and sockeye (O. nerka) salmon at $15^{\circ} \mathrm{C}$. Can. J. Fish. Aquat. Sci. 38, 399-404.

Brown, J.A., Jones, A., Matty, A.J., 1984. Oxygen metabolism of farmed turbot (Scophthalmus maximus). I. The influence of fish size and water temperature on metabolic rate. Aquaculture 36, 273-281.

Burel, C., Person-Le-Ruyet, J., Gaumet, F., Le Roux, A., Sévère, A., Boeuf, G., 1996. Effects of temperature on growth and metabolism in juvenile turbot. J. Fish Biol. 49, 678-692. 
Cech, J.J., Mitchell, S. J., Wragg, T. E., 1984. Comparative growth of juvenile white sturgeon and striped bass: effects of temperature and hypoxia. Estuaries 7, 12-18.

Dalla Via, J., van den Thillart, G., Cattani, O., de Zwaan, A., 1994. Influence of long-term hypoxia exposure on the energy metabolism of Solea solea. II. Intermediary metabolism in blood, liver and muscle. Mar. Ecol. Prog. Ser. 111, 17-27.

Dosdat, A., Gaumet, F., Chartois, H., 1994. Marine aquaculture effluent monitoring: methodological approach to the evaluation of nitrogen and phosphorus excretion by fish. Aquacult. Eng. 14, 59-84.

Dosdat, A., Metailler, R., Tetu, N., Servais, F., Chartois, H., Huelvan, C., Desbruyeres, E., 1995. Nitrogenous excretion in juvenile turbot, Scophthalmus maximus L., under controlled conditions. Aquacult. Res. 26, 639-650.

Fritsche, R., Nilsson, S., 1993. Cardiovascular and ventilatory control during hypoxia In: Rankin, J. C., Jensen F. B. (Eds.), Fish Ecophysiology. Chapman \& Hall, London, pp. 180206.

Gaumet, F., Boeuf, G., Sévère, A., Le Roux, A., Mayer-Gostan, N., 1995. Effects of salinity on the ionic balance and growth of juvenile turbot. J. Fish Biol. 47, 865-876.

Imsland, A.K., Folkvord, A., Stefansson, S.O., 1995. Growth, oxygen consumption and activity of juvenile turbot (Scophthalmus maximus) reared under different temperatures and photoperiods. Neth. J. Sea Res. 34, 149-159.

Imsland, A.K., Folkvord A., Jónsdóttir, Ó. D.B., Stefansson S.O., 1997. Effects of exposure to extended photoperiods during the first winter on long-term growth and age at first maturity in turbot (Scophthalmus maximus). Aquaculture 159, 125-141.

Jensen, F.B., Nikinmaa, M., Weber, R.E., 1993. Environmental perturbations of oxygen transport in teleost fishes: causes, consequences and compensations. In: Rankin, J. C., Jensen F. B. (Eds.), Fish Ecophysiology. Chapman \& Hall, London, pp. 161-179.

Jobling, M., Davies, P. S., 1980. Effects of feeding on metabolic rate, and the Specific Dynamic Action in plaice, Pleuronectes platessa L. J. Fish Biol. 16, 629-638.

Jobling, M., 1994. Fish Bioenergetics, Vol. XIV. Chapman \& Hall, London, 309 pp. 
Kaushik, S., J., 1980. Influence of nutritional status on the daily patterns of nitrogen excretion in the carp (Cyprinus carpio L.) and the rainbow trout (Salmo gairdneri R.). Reprod. Nutr. Develop. 20, 1751-1765.

Lamers, A.E., Flik, G., Atsma, W., Wendelaar Bonga, S.E., 1992. A rôle of di-acetyl-alphamelanocyte-stimulating hormone in the control of cortisol release in the teleost Oreochromis mosambicus. J. Endocrinol. 135, 285-292.

Maxime, V., Pichavant, K., Boeuf, G., Nonnotte, G. 1999. Effects of hypoxia on respiratory physiology of turbot, Psetta maxima. Fish. Physiol. Biochem., in press.

Pedersen, C. L., 1987. Energy budgets for juvenile rainbow trout at various oxygen concentrations. Aquaculture 62, 289-298.

Person-Le-Ruyet, J., Baudin-Laurencin, F., Devauchelle, N., Métailler, R., Nicolas, J.L., Robin, J., Guillaume, J., 1991. Culture of turbot (Scophthalmus maximus). In: McVey, J.P. (Ed.), CRC Handbook of Mariculture, Vol. II. Finfish Aquaculture. CRC Press, Boca Raton, pp. 77-82.

Person-Le-Ruyet, J., 1993. L’élevage du turbot en Europe. La pisciculture française 112, 522.

Person-Le-Ruyet, J., Galland, R., Le Roux, A., Chartois, H., 1997. Chronic ammonia toxicity in juvenile turbot (Scophthalmus maximus). Aquaculture 154, 155-171.

Pichavant, K., Person-Le-Ruyet, J., Sévère, A., Le Roux, A., Quéméner, L., Boeuf, G., 1998. Capacités adaptatives du turbot (Psetta maxima) juvénile à la photopériode. Bull. Fr. Pêche Piscic. 350-351, 265-277.

Pouliot, T., De La Noüe J., 1989. Feed intake, digestibility and brain neurotransmitters of rainbow trout under hypoxia. Aquaculture 79, 317-327.

Thetmeyer, H., Waller, U., Black, K.D., Inselmann, S., Rosenthal, H., 1999. Growth of European sea bass (Dicentrarchus labrax L.) under hypoxic and oscillating oxygen conditions. Aquaculture 174, 355-367.

Thillart van den, G., Dalla Via, J., Vitali, G., Cortesi, P., 1994. Influence of long-term hypoxia exposure on the energy metabolism of Solea solea. I. Critical $\mathrm{O}_{2}$ levels for aerobic and anaerobic metabolism. Mar. Ecol. Prog. Ser. 104, 109-117. 
Van Dam, A. A., Pauly, D., 1995. Simulation of the effects of oxygen on food consumption and growth of Nile tilapia, Oreochromis niloticus (L.). Aquacult. Res. 26, 427-440.

Waller, U., 1992. Factors influencing routine oxygen consumption in turbot, Scophthalmus maximus. J. Appl. Ichthyol. 8, 62-71. 